\title{
Impact of Mineral Fertilizers with or without Bio-Fertilizers or Potassium Humate on some Soil Properties, Yield and Quality of Pea Plants Under Salt Affected Soil Conditions

\author{
Khafagy, H. A. ; Marwa A. A. Ahmed and Seham M. Abdel-Azeem \\ Soil, Water and Environmental Res. Institute, ARC, Giza, Egypt
}

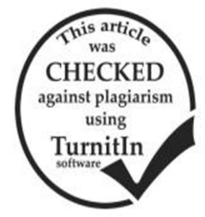

\section{ABSTRACT}

Two field experiments were conducted in clay salt affected soil in Sahl El-Hussinia, El-Sharkia Governorate, Egypt, during two winter seasons2016/2017and2017/2018 to evaluate the effect of mineral fertilizers with different rates(10- 20- $40 \mathrm{~kg} / \mathrm{fed}$. N); (15- 25- 30 $\mathrm{kg} /$ fed. $\mathrm{P}_{2} \mathrm{O}_{5}$,) and (20 $-30-40 \mathrm{~kg} /$ fed. $\mathrm{K}_{2} \mathrm{O}$,) alone or with bio-fertilizers or potassium humate on some soil properties (available $\mathrm{N}$, $\mathrm{P}$, $\mathrm{K}, \mathrm{Fe}, \mathrm{Mn}, \mathrm{Zn}$ and E.C), yield and quality of pea plants. The results revealed that the studied the soil salinity EC $\left(\mathrm{dSm}^{-1}\right) \mathrm{decreased} \mathrm{in}^{-}$ soil treated with potassium humate and bio-fertilizers with mineral fertilizers compared with control. The available soil macronutrients i.e. $\mathrm{N}, \mathrm{P}, \mathrm{K}$, and micronutrients i.e. Fe, $\mathrm{Mn}$ and $\mathrm{Zn}(\mathrm{mg} / \mathrm{kg}$ soil) after harvesting in soils treated with biofertilizers and potassium humate with or without mineral fertilizers were increased with increasing mineral fertilizers (NPK) rates. Concerning, the relative increases of all estimated parameters pea plants in both seasons shows gradually increases as follows: potassium humate $>$ bio-fertilizers $>$ mineral fertilizers $>$ control for plant height $(\mathrm{cm})$, number of branches/ plant, pods/ plants and weight 100 seeds. While, the bio-fertilizers $>$ potassium humate $>$ mineral fertilizers $>$ control for No. of seeds /pods in both seasons. Also, using potassium humate, biofertilizers and mineral fertilizers led to significant increases for dry weight/plant, fresh pod /plant ( $\mathrm{g}$ ) and yield of pods ton/fed. As well as, potassium humate and biofertilizers in combination with NPK chemical fertilizers increased P and K concentration in seeds. Mineral fertilizers (NPK) combined with or without potassium humate and bio-fertilizers increased on Fe, Mn and Zn concentrations in pea seeds in both seasons. The micronutrients were increased with increasing rate of chemical fertilizers as compared without bio-fertilizers or potassium humate. The interaction between all treatments and mineral fertilizers rates led to significant increase in carbohydrate and proline contents of seeds, while the total sugar content in pea plants was unsignificant. Further, combined application of potassium humate and inorganic fertilizers improved the soil properties. This characterizes the synergistic effect of potassium humate and biofertilizers combined with mineral fertilizers thereby signifying that integrated use of inorganic, organic and biofertilizers helps in upgrading soil health.

Keywords: Potassium humate, bio-fertilizers, mineral fertilizations, saline soil, pea productivity.

\section{INTRODUCTION}

Egypt is considered to be a heavy user of chemical fertilizers especially nitrogen followed by phosphorous then potassium. The consumed amount of NPK in 2002 was $488 \mathrm{~kg} / \mathrm{ha}$. The production of chemical nitrogenous fertilizers in 2002 in thousand tons was 1645 Ammonia, 1865 Urea and 1070 Ammonium nitrate, since the production of phosphate fertilizers also in thousand tons was 1670 Rock phosphate, 20 phosphoric acid,940 single Super phosphate $15 \% \mathrm{P}_{2} \mathrm{O}_{5}$ and 50 concentrated Super phosphate $(37 \% \mathrm{P} 2 \mathrm{O} 5)$, while the imported Potassium Sulfate $\left(48 \% \mathrm{~K}_{2} \mathrm{O}\right)$ was 80000 tons. The consumed, N: $\mathrm{P}_{2} \mathrm{O}_{5}: \mathrm{K}_{2} \mathrm{O}$ ratio was 63:12:1 in 1981 and declined to $36: 5: 1$ in 2002 due to the high consumed SOP in the last 20 years, Abd El-Hadi (2004).

The reclamation of salt affected soil requires an improvement of physical, chemical biological properties. Soil humic substances (HS) such as potassium humate (HA) and fulvic acid (FA), are mainly derived from the (bio) chemical degradation of plant and animal residues and from microbial synthetic activity and they constitute a significant fraction of the soil organic matter $(65-70 \%)$ (Gulser et al., 2010).

Nitrogen, phosphorus and potassium are key nutrients that play a major role in crop production on intensively cultivated soils. The soil fertility is directly influenced by the type of fertilizer inputs, Harleen et al (2017).

Biofertilizers are play an important role in increasing availability of nitrogen and phosphorus by improving biological fixation of atmospheric nitrogen as well as enhancing phosphorus availability to crop (Bhat et al., 2013). Sarg and Hassan (2003) indicated that Rhizobium inoculation caused a significantly increased plant height, number of leaves and branches as well as number of nodules compared with uninoculated. Rather et al.(2010) found that application of Rhizobium Azotobacter and phosphate solubilizing bacteria (PSB)) increased pea growth, yield, number of pods/ plant, number of seeds/pod, pod length and 1000 grain compared untreated.

Potassium humate (HA) is important component produced by the chemical and biological decomposition of organic material through the help of micronutrients. Potassium humate is a vital component of soil organic matter which improves the growth of many plant species. It enhances soil fertility and improves physical and chemical characteristics of soil, like permeability, aeration, aggregation, water holding capacity, ion transport and availability through $\mathrm{pH}$ buffering (Afifi et al., 2010). Sarwar et al.,(2012) found that using potassium humate at $50 \mathrm{mg} \mathrm{kg}$ alone with $100 \%$ recommended dose of $\mathrm{P}$ fertilizer significantly enhanced grain weight $72 \%$ and number of pods/plant $22 \%$ of pea plants compared with $100 \%$ recommended dose of $P$ fertilizer alone.

Pea (Pisum sativum L.) is one of the most important leguminous vegetable crops grown during winter season in Egypt. It occupies a great figure in the local consumption and export. The total area grown with garden peas in Egypt was 47951 fed, which produced 180631 ton with an average yield 3.77 ton/fed, while dry peas was 162 fed and average productivity $0.77 \mathrm{ton} / \mathrm{fed}$ according to agricultural statistics, Ministry of Agriculture, 2012). Pea used in human diet and it is rich in protein, carbohydrates and vitamin and it has high levels of amino acids lysine and tryptophan (Bhat et al., 2013).

This study aims to evaluate the effect of using mineral fertilizers combined with or without different biofertilizers and potassium humate on soil fertility and yield 
components, N, P, K, Fe, Mn and Zn contents in soil and on pea yield and seeds quality under saline soil.

\section{MATERIALS AND METHODS}

Two field experiments were carried out in clay salt affected soil of private from at Sahl El-Hussinia in El-
Sharkia Governorate, Egypt, during two successive seasons of winter, 2016/ 2017 and 2017/ 2018.

A-Physical and chemical properties of the soil used

The physical and chemical properties of the soil were determined before planting according to Cottenie et al (1982), Page et al (1982) and Klute (1986). The obtained data were recorded in Table (1).

Table 1. Soil physical and chemical properties of the experimental sites

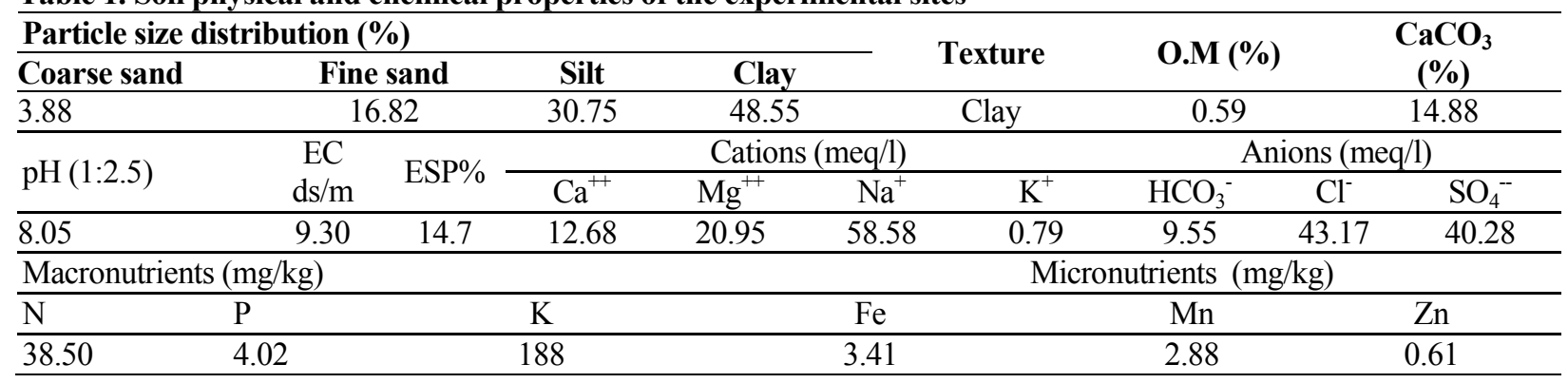

\section{B- Bio-fertilizers}

Bio-fertilizers were Rhizobium radiobacter $\mathrm{sp}$ strain (Salt Tolerant PGPR), Bacillus megatherium for dissolving phosphate and Bacellus circulans for potassium availability. The bio- fertilizers were obtained from Department of Microbiology, Soils, Water and Environment Research Institute, Agriculture Research center, Giza, Egypt.

Pea (Pisum sativum L.) cv Entsar 1 Varity seeds were supplemented from Veget. Res. Dept., Hort. Res. Inst., Agric. Res. Center, Egypt.

\section{C-Field experimental:}

The soils of all the studies experimental pilot units are subjected to some pretreatments processes as follows:-

a) Leveling the soil surface by using lazar technique. b) Deep sub-soiling plough. c) Establishment of filed drains at a distance of $10 \mathrm{~m}$ between each of tow drains and a deep of $90 \mathrm{~cm}$ at drain beginning, their drainage water flow towards the main collectors of $2 \mathrm{~m}$ in depth, and d) Establishment of an irrigation canal in the middle part of the experimental pilot unit.

Seeds of pea was inoculated with Rhizobium radiobacter applied at a rate of $100 \mathrm{~g}$ for $25 \mathrm{~kg}$ seeds wetted with $400 \mathrm{ml}$ of adhesive liquid (Arabic gum). Seeds were thoroughly mixed with the inoculum in the shaden then sown immediately and covered with soil in order to minimize Rhizobium radiobacter exposure to the sun and the air. Bacillus megatherium was used as phosphate dissolving bacteria was foliar application on soil at rate $25 \mathrm{~L}$ bio-fertilizer $/ 400 \mathrm{~L}$ water/fed before planting. The super phosphate $\left(15.5 \% \mathrm{P}_{2} \mathrm{O}_{5}\right)$ was applied at rates of 15,25 and $30 \mathrm{~kg}\left(15.5 \% \mathrm{P}_{2} \mathrm{O}_{5}\right) /$ fed during tillage soil.
Bacillus circulans for potassium availability was applied after 21 and 45 days from planting at rate $25 \mathrm{~L}$ Bacillus circulans / $400 \mathrm{~L}$ water.

Potassium humate was application on soil at rate 20 $\mathrm{kg} /$ fed in same day of planting .Chemical composition of the used potassium humate is shown in Table (2). The potassium humate analysis was done according to the standard methods described by Brunner and Wasmer (1978)

Table 2. Chemical properties of used potassium humate.

\begin{tabular}{ccccccccc}
\hline \multirow{2}{*}{$\mathbf{p H}$} & \multirow{2}{*}{$\begin{array}{c}\text { EC } \\
\left(\mathbf{d S m}^{-1}\right)\end{array}$} & $\begin{array}{c}\text { O.M. } \\
\mathbf{( \% )}\end{array}$ & \multicolumn{2}{c}{$\begin{array}{c}\text { Macronutrients } \\
(\mathbf{\%})\end{array}$} & \multicolumn{3}{c}{$\begin{array}{c}\text { Micronutrients } \\
\left(\mathbf{m g ~ k g}^{-1}\right)\end{array}$} \\
\cline { 5 - 9 } & & $\mathbf{N}$ & $\mathbf{P}$ & $\mathbf{K}$ & $\mathbf{F e}$ & $\mathbf{~ M n}$ & $\mathbf{~ Z n}$ \\
\hline 7.64 & 2.44 & 76 & 2.34 & 0.43 & 3.88 & 425 & 277 & 210 \\
\hline
\end{tabular}

Seeds sowing were carried out at 15 October 2016 and 2017. Three of coated seeds were sown in hole with 25 $\mathrm{cm}$ and $5 \mathrm{~cm}$ depth. After 31 days from planting, the plant was thinned to one plant of each hole. Urea $(46 \% \mathrm{~N})$ was applied as $\mathrm{N}$ fertilizer at rates of 10,20 and $40 \mathrm{~kg} \mathrm{~N}^{-1} \mathrm{fe}^{-1}$ on three equal doses after 21, 42 and 62 days from sowing. Potassium sulphate $\left(48 \% \mathrm{~K}_{2} \mathrm{O}\right)$ was applied at rates 20,30 and $40 \mathrm{~kg} \mathrm{~K}_{2} \mathrm{O}$ fed $^{-1}$ on two equal doses after 21 and 42 days from planting. The all experimental plots were irrigated water by El-Salam canal, which characterized by the mean chemical composition recorded in Table (3). These analyses were carried out during growth seasons of pea. The properties of the used irrigation water were determined according to Cottenie et al (1982).

Table 3. Analysis of irrigation water from in El-Salam Canal.

\begin{tabular}{lcccccccc}
\hline \multirow{2}{*}{$\mathbf{p H}(\mathbf{1 : 2 : 5 )}$} & $\begin{array}{c}\mathbf{E C} \\
\mathbf{d S} / \mathbf{m})\end{array}$ & $\mathbf{C a}^{++}$ & $\mathbf{M g}^{++}$ & $\mathbf{N a}^{+}$ & $\mathbf{K}^{+}$ & $\mathbf{H C O}_{\mathbf{3}}^{-}$ & $\mathbf{C l}^{-}$ & $\mathbf{S O}_{4}^{-}$ \\
\hline 7.85 & 1.75 & 3.40 & 5.89 & 7.36 & 0.85 & 2.88 & 6.22 & 8.40 \\
\hline Macronutrients $(\mathrm{mg} / \mathrm{L})$ & & & & & & Micronutrients $(\mathrm{mg} / \mathrm{L})$ & \\
\hline $\mathrm{NO}_{3}-\mathrm{N}$ & $\mathrm{NH}_{4}-\mathrm{N}$ & $\mathrm{P}$ & $\mathrm{K}$ & $\mathrm{Fe}$ & $\mathrm{Mn}$ & $\mathrm{Zn}$ \\
\hline 22.10 & 9.30 & 4.00 & 7.31 & & 3.45 & 2.89 & 0.089 \\
\hline
\end{tabular}

The experiment was carried out in a split plot design with three replicates in both seasons each. The used three sources (mineral, bio-fertilizer and potassium humate) were a ranged randomly as main plot, where the rates of mineral fertilizers were distributed randomly as sub plot. The experimental included the following treatments: 
I. The main plot (mineral fertilizers)

1- Without mineral NPK fertilizers

2- Mineral NPK fertilizers at $10-15-20 \mathrm{~kg} / \mathrm{fed}$

3- Mineral NPK fertilizers at $20-25-30 \mathrm{~kg} / \mathrm{fed}$

4- Mineral NPK fertilizers at $40-30-40 \mathrm{~kg} / \mathrm{fed}$

П. The sub plot (bio-fertilizers or potassium humate)

1- Control

2- Bio-fertilizers at $100 \mathrm{~g}$ for $25 \mathrm{~kg}$ seeds

3- Potassium humate at $20 \mathrm{~kg} / \mathrm{fed}$

At harvesting stage (120 days from sowing), the plants of each experimental unit were harvested, fresh yield of pods and seeds were weighted $(\mathrm{kg})$, plant height $(\mathrm{cm})$, number of branches /plant, number of pods/plant and number of seeds/pod. Samples of seeds were air-dried and oven dried at $70 \mathrm{C}$ for $48 \mathrm{hrs}$ and $0.5 \mathrm{~g}$ was digested using $\mathrm{H}_{2} \mathrm{SO}_{4}, \mathrm{HCIO}_{4}$ mixture according to the method described by Chapman and Pratt (1961). Seeds contents of N, P, K, $\mathrm{Fe}, \mathrm{Mn}$ and $\mathrm{Zn}$ were determined using the methods described by Cottenie et al (1982) and Page et al(1982). Protein percentage of seeds was calculated by multiplying the nitrogen percentage by the factor 6.25 Hymowitz et al (1972).

The obtained data were statistically analysis using the COSTAT program and L.S.D. test at the probability levels of $5 \%$ was calculated according to Gomez and Gomez (1984).

\section{RESULTS AND DISCUSSION}

Soil salinity $\left(\mathrm{EC} \mathrm{dSm}^{-1}\right)$.

The data in Table (4) reveal that application of potassium humate or biofertilizers combined with different rate of mineral fertilizers decreased soil salinity. The applied of potassium humate and bio-fertilizers combined with mineral fertilizers were significantly by decreased soil salinity. The application of potassium humate combined with mineral fertilizers gave the highest decrease in the salinity soil compared with the other treatments. Theses results may be due to the activation of bacteria in soil caused by potassium humate and bio-fertilizers addition and the influence of bio-fertilizer or potassium humate on total porosity, and improving soil aggregation and possible moving salt soil under irrigation water. Theses results are in agreement with Sushila et al (2017),they suggested that the application of biofertilizers on saline soil decrease soil salinity because the bio-fertilizers activate microorganisms in soil and dehydrogenase enzyme production in soil led to decrease the soil salinity compared with control. Mohamed (2012) reported that by application of potassium humate, soil salinity was significantly decreased..Shaban and Attia (2009) showed that the values of EC were decreased with the increase mineral fertilizer in combination with biofertilizer as compared with chemical fertilizers alone. The potassium humate application led to decrease soil $\mathrm{Na}$ and EC likely due to high supplies of $\mathrm{Ca}, \mathrm{Mg}$ and $\mathrm{K}$. In fact, the reduction of soil salinity means reducing in the monovalent $\mathrm{Na}+$ and this is particularly evident when the replace of the monovalent $\mathrm{K}^{+}$to the humate (salt) of the humic complex occurred(Ouni et al .2014). Ali et al (2013)mentioned that potassium humate application to soil led to decrease of soil salinity (EC) ,which may be improve the physical chemical and biological properties of soil,

Table 4. Mean values of EC and macro-micronutrients available in soil after the two seasons as affected by the interaction between soil amendments and $\mathrm{N}, \mathrm{P}$ and $\mathrm{K}$ levels.

\begin{tabular}{|c|c|c|c|c|c|c|c|c|c|c|}
\hline \multirow{2}{*}{ Treatment } & \multicolumn{3}{|c|}{ Minerals rates (kg/fed) } & \multirow{2}{*}{$\begin{array}{c}\mathrm{EC} \\
\left(\mathrm{dSm}^{-1}\right)\end{array}$} & \multicolumn{3}{|c|}{ Macronutrients $\left(\mathrm{mgkg}^{-1}\right)$} & \multicolumn{3}{|c|}{ Micronutrients $\left(\mathrm{mgkg}^{-1}\right)$} \\
\hline & $\mathbf{N}$ & $\mathbf{P}_{2} \mathbf{O}_{4}$ & $\mathrm{~K}_{2} \mathrm{O}$ & & $\mathbf{N}$ & $\mathbf{P}$ & $\mathbf{K}$ & $\mathbf{F e}$ & Mn & $\mathbf{Z n}$ \\
\hline \multirow{4}{*}{ Control } & 0 & 0 & 0 & 7.34 & 40.35 & 4.55 & 192.00 & 3.58 & 2.93 & 0.650 \\
\hline & 10 & 15 & 20 & 6.37 & 41.85 & 4.89 & 197.00 & 3.75 & 2.97 & 0.690 \\
\hline & 20 & 25 & 30 & 5.85 & 41.96 & 4.95 & 201.00 & 3.96 & 3.04 & 0.710 \\
\hline & 40 & 30 & 40 & 5.23 & 42.16 & 5.06 & 205.00 & 4.03 & 3.09 & 0.730 \\
\hline \multirow{4}{*}{ Bio-fertilizers } & 0 & 0 & 0 & 7.10 & 41.32 & 4.88 & 197.00 & 3.68 & 2.97 & 0.690 \\
\hline & 10 & 15 & 20 & 5.35 & 43.85 & 5.03 & 205.00 & 3.89 & 3.04 & 0.740 \\
\hline & 20 & 25 & 30 & 4.85 & 47.63 & 5.12 & 210.00 & 3.98 & 3.11 & 0.790 \\
\hline & 40 & 30 & 40 & 3.90 & 51.05 & 5.16 & 218.00 & 4.18 & 3.19 & 0.820 \\
\hline \multirow{4}{*}{$\begin{array}{l}\text { Potassium } \\
\text { humate }\end{array}$} & 0 & 0 & 0 & 8.01 & 41.89 & 4.93 & 199.00 & 3.74 & 3.01 & 0.720 \\
\hline & 10 & 15 & 20 & 5.10 & 44.25 & 5.09 & 206.00 & 3.96 & 3.08 & 0.790 \\
\hline & 20 & 25 & 30 & 4.19 & 49.37 & 5.18 & 212.39 & 4.02 & 3.15 & 0.810 \\
\hline & 40 & 30 & 40 & 3.35 & 52.38 & 5.23 & 223.00 & 4.20 & 3.24 & 0.850 \\
\hline \multicolumn{4}{|c|}{ LSD at 0.05 rates } & 0.28 & 0.61 & 0.068 & 1.16 & 0.076 & 0.068 & 0.024 \\
\hline \multicolumn{4}{|c|}{ LSD at 0.05 treatments } & 0.32 & 0.70 & 0.13 & 1.15 & 0.062 & 0.078 & 0.045 \\
\hline \multicolumn{4}{|c|}{ LSD at 0.05 interaction } & 0.49 & 1.06 & 0.118 & 2.02 & 0.132 & 0.118 & 0.043 \\
\hline
\end{tabular}

\section{Macronutrients available in soil.}

Data presented in Table (4) show that after pea harvesting the available soil contents macronutrients i.e. $\mathrm{N}$, $\mathrm{P}$ and $\mathrm{K}(\mathrm{mg} / \mathrm{kg}$ soil) in soils treated with biofertilizers and potassium humate with or without mineral fertilizers were increased with increasing mineral fertilizers (NPK) rates. The highest mean values of 46.97, 5.10 and $210(\mathrm{mg} / \mathrm{kg})$ for $\mathrm{N}, \mathrm{P}$ and $\mathrm{K}$ contents were found in soil treated with potassium humate compared with other treatments. This may be due to organic acids produced during the degradation of such organic materials (as well as humates) as a result of the microorganisms activities must have contributed to a decrease in soil $\mathrm{pH}$ which produce more chelating ions, leading to an increase in available forms of elements in the rhizosphere zone. In addation, the bio fertilization effect could be due to active organic acids produced by microflora during microbial activity, thus enhancing solubilization of nutrients. These results are in 
agreement with El-Galad et al., (2013) ,they mentioned that application of potassium humate or compost in saline soil gave the highest soil available N, P and $\mathrm{K}$ values after harvesting. Hassan (2016) reported that the increase of available N, P and $\mathrm{K}$, contents in soil was affected by potassium humate application. Zaghloul et al (2015) found that the lowest values of total nitrogen, phosphorus and potassium were observed in soil treated with chemical fertilizers alone

\section{Micronutrients available contents in soil.}

Data in Table (4) reveal that the contents of available $\mathrm{Fe}, \mathrm{Mn}$ and $\mathrm{Zn}(\mathrm{mg} / \mathrm{kg}$ soil) in soil treated with bio-fertilizers and potassium humate combined with mineral fertilizers were increased with increasing mineral fertilizers. The application of potassium humate and biofertilizers led to increases in Fe, Mn and $\mathrm{Zn}$ contents of soil after harvesting. Available micronutrients were significantly increased with increasing rate of mineral fertilizers compared with control. The maximum mean values of $\mathrm{Fe}, \mathrm{Mn}$ and $\mathrm{Zn}$ contents were found in soil treated with potassium humate combined with different rates mineral fertilizers compared with other treatments. These results are in agreement with Shaban and Attia (2009), they revealed that the content of available Fe, Mn, $\mathrm{Zn}$ and $\mathrm{Cu}(\mathrm{mg} / \mathrm{kg})$ were increased as affected by biofertilizers including Azospirillum brasilense NO 40, Bacillus megatherium and Bacillus circulans in combination with chemical fertilizers. Also, Wu et al (2006) found that, the activity of Azotobacter chroococcum, Bacillus megatherium and Bacillus mucilaginosus, led to an increase of water dissolved organic carbon concentration and a decreased in $\mathrm{pH}$ value, which enhanced metal mobility and bio-availability. Also, Hussein and Hassan (2011) reported that potassium humate importance due to their ability to chelate micronutrients, thus increasing their bio-availability. Galad et al., (2013) indicated that application of potassium humate to saline soil gave the highest soil available Fe, $\mathrm{Mn}$ and $\mathrm{Zn}$ values after harvesting.
Effect of different mineral fertilizers rates combined with or without bio-fertilizers on pea parameters.

Data in Table (5) showed the increase of plant height, number of branches /plant, pods/plant, seeds/pod and weight of 100 seeds as affected with mineral fertilizers different rates combined with bio-fertilizers. The highest values of plant height, number of branches /plant,. pods/plant, seeds/pod and weight of 100 seeds were noticed in plants treated with N,P, K mineral fertilizers at a rate 20-25- 30 combined with bio-fertilizers compared with other treatments. The effect of different rates of mineral fertilizers on all growth parameters were significantly increased in both seasons, while the all treatments application have unsignificant effect on plant height $(\mathrm{cm})$, number of pods/plant and weight of 100 seeds in both seasons, while the number of branches was significantly increased in both seasons. On the other hand, the interaction between all treatments at different rates on all plant parameters was significantly increased in both seasons. The relative increases of mean values were 34.13 $\%$ for plant height , $48.16 \%$ for number of branches/ plant, $73.12 \%$ for number of pods/ plants, $29.98 \%$ for number of Seeds /pod and $150.78 \%$ for weight 100 seeds as plants treated with different rates of mineral fertilizers without bio-fertilizers compared with mean values of control in both seasons. Also, the relative increases of mean season's values $50.78 \%$ for plant height , $65.44 \%$ for No. branches/ plant, $102.15 \%$ for number of pods/ plants, $81.54 \%$ for number of seeds /pod and $168.41 \%$ for weight 100 seeds as affected by different mineral fertilizers rates combined with bio-fertilizers than mean values of control. As well as, the relative increases of mean values were 69 . $78 \%$ for plant height $(\mathrm{cm}), 80.88 \%$ for No. branches/ plant, $129.03 \%$ for No. pods/ plants, $66.00 \%$ No. of Seeds /pod and $197.60 \%$ for weight 100 seeds (g) as affected by potassium humate combined with different rates of mineral fertilizers compared with the mean values of mineral fertilizers in both seasons.

Table 5. Pea growth as affected by mineral fertilizers with or without bio-fertilizers or potassium humate at 120 days after sowing through 2016/2017and2017/2018 experiment seasons.

\begin{tabular}{|c|c|c|c|c|c|c|c|c|c|c|c|c|c|c|c|c|c|c|}
\hline \multirow[t]{2}{*}{ Treatment } & \multicolumn{3}{|c|}{$\begin{array}{c}\text { Minerals rates } \\
\text { (kg/fed) }\end{array}$} & \multicolumn{3}{|c|}{$\begin{array}{l}\text { Plant height } \\
\text { (cm) }\end{array}$} & \multicolumn{3}{|c|}{$\begin{array}{c}\text { No. of branches } \\
\text { /plant }\end{array}$} & \multicolumn{3}{|c|}{$\begin{array}{c}\text { No. of } \\
\text { pods/plant }\end{array}$} & \multicolumn{3}{|c|}{$\begin{array}{c}\begin{array}{c}\text { No. of } \\
\text { seeds/pod }\end{array} \\
\end{array}$} & \multicolumn{3}{|c|}{$\begin{array}{l}\text { Weight of } 100 \text { seeds } \\
(\mathrm{g})\end{array}$} \\
\hline & $\mathbf{N}$ & $\mathbf{P}_{2} \mathbf{O}_{4}$ & $\mathbf{K}_{2} \mathbf{O}$ & S1 & S2 & Mean & S1 & S2 & Mean & S1 & S2 & Mean & S1 & S2 & Mean & S1 & S2 & Mean \\
\hline \multirow{4}{*}{ Control } & 0 & 0 & 0 & 35.24 & 37.17 & 36.21 & 2.25 & 2.55 & 2.40 & 3.85 & 3.95 & 3.90 & 2.89 & 3.10 & 3.00 & 6.20 & 6.99 & \\
\hline & 10 & 15 & 20 & 9.63 & 51.34 & 49 & 3.65 & 3.89 & 3.7 & 7.36 & 7.94 & 7.65 & 5.96 & 6.34 & 6. & 16.89 & 17.12 & \\
\hline & 20 & 25 & 30 & 51.22 & 5 & & 3.95 & 4.22 & 4.09 & 7.88 & 8.23 & 8.06 & 6.85 & 7.30 & 7.08 & 17.20 & & \\
\hline & 40 & & & 54.26 & & .73 & 4.15 & 4.33 & 4.2 & 8.20 & 8.66 & 8.43 & 7.85 & 8.32 & 8.09 & & & \\
\hline \multirow[t]{2}{*}{ Mean } & & & & 47.59 & 49.20 & 3.40 & 3.50 & 3.75 & & 6.82 & 7.20 & 7.01 & 5.89 & 6. & 6.08 & & 15 & \\
\hline & 0 & 0 & 0 & 38.21 & & & 2.56 & 2.89 & & 4.78 & 4.88 & & 4.63 & & 4.76 & & & \\
\hline \multirow{3}{*}{$\begin{array}{l}\text { Bio- } \\
\text { fertilizers }\end{array}$} & 10 & 15 & 20 & 52.34 & & 5 & 3.86 & 4.23 & 4.0 & 8.14 & 8.36 & 8.25 & 9.34 & 9.55 & 9.45 & & & \\
\hline & 20 & 25 & 30 & 61.00 & 63.52 & 62.26 & 4.88 & 5.10 & 4.99 & 10.36 & 10.52 & 10.44 & 10.12 & 10.59 & 10.36 & 19.34 & 85 & \\
\hline & 40 & 50 & 40 & 59.45 & 61. & 60.65 & 4.37 & 4.55 & 4.4 & 9.23 & 9.78 & 9.51 & 9.88 & 10.10 & 9.99 & & & \\
\hline \multirow[t]{2}{*}{ Mean } & & & & 52.75 & 55.7 & .23 & 3.92 & 4.19 & 4.0 & 8.13 & 8.39 & 8.26 & 8.49 & 8. & 8.64 & & & \\
\hline & 0 & 0 & 0 & 39.52 & 42.68 & 41.10 & 2.94 & 3.12 & 3.03 & 5.12 & 5.29 & 5.21 & 5.69 & 5.89 & 8.64 & 32 & .88 & 7.60 \\
\hline \multirow{3}{*}{ Humic acid } & 10 & 15 & 20 & 63.58 & 65.43 & 64.51 & 3.89 & 4.22 & 4.0 & 9.52 & 9.73 & 9.63 & 10.23 & 10.58 & 5.79 & 19.41 & & 19.50 \\
\hline & 20 & 25 & 30 & 65.28 & 67.85 & 66.57 & 5.03 & 5.18 & 5.11 & 10.89 & 11.30 & 11.10 & 10.85 & 11.22 & 10.41 & & & 20.95 \\
\hline & 40 & 30 & 40 & 66.89 & 69.33 & 68.11 & 5.55 & 5.63 & 5.59 & 10.95 & 11.46 & 11.21 & 11.15 & 11.63 & 11.04 & 22. & 22.89 & 22.84 \\
\hline \multicolumn{4}{|c|}{ Mean } & 58.82 & 61.32 & 60.07 & 4.35 & 4.54 & 4.45 & 9.12 & 9.45 & 9.28 & 9.48 & 9.83 & 9.66 & 17.57 & 17.87 & 11.39 \\
\hline \multicolumn{4}{|c|}{ LSD. $0.05 \%$ Rate } & 1.58 & 1.89 & --- & 0.05 & 0.07 & --- & 0.40 & 0.61 & --- & 0.32 & 0.60 & ---- & 1.90 & 0.95 & ----- \\
\hline \multicolumn{4}{|c|}{ LSD. $0.05 \%$ treatments } & Ns & ns & --- & 0.03 & 0.09 & ---- & ns & Ns & ---- & $\mathrm{ns}$ & 0.25 & --- & ns & ns & ----- \\
\hline \multicolumn{4}{|c|}{ Rate $\mathrm{X}$ treatments } & $* * *$ & $* * *$ & --- & $* * *$ & $* * *$ & -- & *** & *** & ---- & $* * *$ & $* * *$ & ---- & $* * *$ & $* * *$ & $\begin{array}{ll}---- \\
\end{array}$ \\
\hline
\end{tabular}


It is worthy to mention that the relative increases of all estimated parameters of pea plants in both seasons showed gradually increases as follows: potassium humate $>$ bio-fertilizers $>$ mineral fertilizers $>$ control for plant height $(\mathrm{cm})$, No. branches/ plant, No. pods/ plants and weight 100 seeds $(\mathrm{g})$, while, the bio-fertilizers $>$ potassium humate $>$ mineral fertilizers $>$ control for No. of seeds /pods in both seasons.

Generally, the pea growth parameters were affected by potassium humate and bio-fertilizers under saline soil because the bio-fertilizers were the best source of plant promoter hormones which enhance plant growth. These results are in agreement with Sarg and Hassan (2003) reported pea growth i.e. plant height, both number of leaves and branches/plant were significantly increased with Rhizobium inoculation compared with the uninoculated .Moreover, Rather et al. (2010) studied the effect of biofertilizers (Rhizobium, Azotobacter and phosphate solubilizing bacteria (PSB)) application on growth, yield and economics of pea. The Co- inoculation of all the three bio-fertilizers i.e. Rhizobium, Azotobacter and PSB produced significant higher growth characters as compared to control. Sarwar et al.,(2012) reported that using soil application of potassium humate at $50 \mathrm{mg} \mathrm{kg}^{-1}$ along with $100 \%$ recommended dose of $\mathrm{P}$ fertilizer significantly enhanced grain weight $72 \%$ and No of pods/plant $22 \%$ as compared to $100 \%$ recommended dose of P fertilizer alone. El-Bassiony et al. (2010) indicated that foliar application by potassium humate $(1,2$ or $3 \mathrm{~g} / \mathrm{l})$ significantly increase all the vegetative growth parameters, i.e. plant height, number of leaves and branches as well as fresh and dry weight of whole snap bean plants.

Effect of bio-fertilizers and potassium humate combined with or without different rates of mineral fertilizers on yield components of pea plants.

Data in Table (6) showed that the plant fresh and dry weight, fresh pod/plant, green seeds yield (ton/fed) and pods yield (ton/fed) were increased as affected with biofertilizer and potassium humate combined with different rates of mineral NPK fertilizers. Increasing rate of mineral fertilizers (NPK) application increase significant was noticed. Also, potassium humate, bio-fertilizers or mineral fertilizers used led to significant increases for dry weight plant, fresh pod/plant and yield of pods (ton/fed) in second season, while the fresh plant was significant increase in the first season. Seed yield (ton/fed) was unsignificant as affected with all treatments in both seasons. The interaction between bio-fertilizers, potassium humate and different rates of mineral fertilizers application gave significant increases for fresh and dry weight, fresh pod/plant $(\mathrm{g})$, green seeds yield (ton/fed) and pods yield (ton/fed) in both seasons. The highest mean values of all growth parameter of pea treated with $40-30-40 \mathrm{~kg} \mathrm{NPK} /$ fed combined with potassium humate were found in both seasons. The increase of mean values of all plant growth parameters was found in plants treated with $20-25-30 \mathrm{~kg}$ NPK mineral fertilizers combined with bio-fertilizers in both seasons. The obtained increase in yield and its components may be due to increase of vegetative growth characters and increase in turn the amount of metabolites synthesized. The relative increases of mean values were $6.40,45.02$ and $57.00 \%$ for fresh weight of plant; $7.13,38.37$ and $47.72 \%$ for dry weight of plant , 45.33,47.43 and $72.62 \%$ for fresh pods/plant, 5.33, 443.48 and $478.26 \%$ for green seeds yield (ton/fed) and $5.87,319.44$ and $402.78 \%$ for pods yield ton/fed as affected with different rates of mineral fertilizers (NPK) alone or combined with bio-fertilizers and potassium humate respectively compared mean values without all treatments. This result may be due to the potassium humate is a natural polymeric composition can be used in order to increase soil fertility and pea yield productivity under saline soil conditions. These results are in agreement with those obtained by Shadisadat et al (2016), they indicated that the potassium humate can improve the plant growth, increase yield components and accumulated photosynthetic matters in (phaseolus vulgaris L). Ghodia (2012) reported that the increase in total green pod yield, number of pod and weight of pods as well as green pod yield/plant on cowpea were increased as affected by bio-fertilizers. It was clearly that pea plants treated only with chemical fertilizers gave lower values of yield and its components than plants treated with biofertilizers and potassium humate.

Table 6. Pea yield and its component as affected by mineral fertilizers with or without bio-fertilizers or potassium humate at 120 days after sowing through 2016/2017and2017/2018 experiment seasons

\begin{tabular}{|c|c|c|c|c|c|c|c|c|c|c|c|c|c|c|c|c|c|c|}
\hline \multirow[t]{2}{*}{ Treatment } & \multicolumn{3}{|c|}{$\begin{array}{c}\text { Minerals rates } \\
(\mathrm{kg} / \mathrm{fed})\end{array}$} & \multicolumn{3}{|c|}{$\begin{array}{c}\text { Fresh weight } \\
\text { /plant (g) }\end{array}$} & \multicolumn{3}{|c|}{$\begin{array}{l}\text { Dry weight } \\
\text { /plant (g) }\end{array}$} & \multicolumn{3}{|c|}{$\begin{array}{c}\text { Fresh pod } \\
\text { /plant (g) }\end{array}$} & \multicolumn{3}{|c|}{$\begin{array}{c}\text { Green seeds } \\
\text { yield/fed (ton) }\end{array}$} & \multicolumn{3}{|c|}{$\begin{array}{l}\text { Weight of pods } \\
\text { yield (ton/fed) }\end{array}$} \\
\hline & $\mathbf{N}$ & $\mathbf{P}_{2} \mathbf{O}_{4}$ & $\mathrm{~K}_{2} \mathrm{O}$ & S1 & S2 & Mean & S1 & S2 & Mean & S1 & S2 & Mean & S1 & S2 & Mean & S1 & S2 & Mean \\
\hline \multirow{4}{*}{ Control } & 0 & 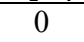 & 0 & & & & 3.47 & & & 14.23 & & & & & & & 0.360 & \\
\hline & 10 & & & & & & & & & & & & & & & & & \\
\hline & & & & & & & & 5.46 & & & & & & & & & & \\
\hline & & & & & & & & 6.04 & & & & & & & & & & \\
\hline & & & & & & & & & & & & & & & & & & \\
\hline \multirow{4}{*}{$\begin{array}{l}\text { Bio- } \\
\text { fertilizers }\end{array}$} & & & & & & & & & & & & & & & & & & \\
\hline & & & & & & & & & & & & & & & & & & \\
\hline & & & & & & & & 6. & & & & & & & & & & \\
\hline & & & & & & & & 5.7 & & & & & & & & & & \\
\hline & & & & & & & 26 & 5.49 & 5.37 & & & & & & & & & \\
\hline \multirow{4}{*}{ Humic acid } & 0 & & & & & & 29 & 4.35 & & & & & & & & & & \\
\hline & 10 & 15 & 20 & & & & 5.62 & 5.89 & 5.7 & 24. & & & & & & & & \\
\hline & 20 & 25 & 20 & & & 38.24 & 6.12 & 6.24 & 6.18 & 25.89 & 27. & & & & 1.399 & & & \\
\hline & 40 & 30 & 40 & & & 39.74 & 6.47 & 6.79 & 6.63 & 26. & & & & & & & & 1.489 \\
\hline & & & & & & 35.03 & 5.63 & 5.82 & 5.72 & 23.64 & 25.90 & 24.77 & 1.034 & 1.080 & 1.060 & 1.671 & & 1.691 \\
\hline \multicolumn{4}{|c|}{ LSD. $0.05 \%$ Rate } & & & --- & 0.65 & & & 3.04 & & & & & --- & & & \\
\hline \multicolumn{4}{|c|}{ LSD. $0.05 \%$ treatments } & & & --- & & 0.24 & & & & & & & -- & & & -- \\
\hline \multicolumn{4}{|c|}{ Rate $\mathrm{X}$ treatments } & $* * *$ & $* * *$ & --- & $* * *$ & $* * *$ & -- & $* * *$ & $* * *$ & ---- & $* * *$ & $* * *$ & ---- & $* * *$ & $* * *$ & 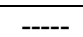 \\
\hline
\end{tabular}

* S1 first season ** S2 second season 
Generally, potassium humate can ameliorate the deleterious effects of salt by increasing root growth, altering mineral uptake and decreasing membrane damage thus pea plant can grow under saline soil conditions. Biofertilizers can reduce soil salinity by reduction application of mineral fertilizers, improving soil fertility by fix $\mathrm{N}_{2}$ atmosphere, and solubilizing soil phosphate rhizosphere region and produce plant growth in the saline soil conditions.

\section{Macronutrients concentrations in pea seeds.}

Data in Table (7) show micronutrients concentration in pea seeds as affected with bio-fertilizers and potassium humate combined with mineral fertilizers at different rates were positive effect. The heights values of $\mathrm{N}, \mathrm{P}$ and $\mathrm{K}$ concentration in seeds were increased with the rate of mineral NPK fertilizers at $40-30-40 \mathrm{~kg} /$ fed alone or combined with potassium humate, combined with mineral fertilizers at different rates were positive effect. The heights values $\mathrm{N}, \mathrm{P}$ and $\mathrm{K}$ concentration in seeds were increasing with rate mineral NPK fertilizers at 40-30- 40 $\mathrm{kg} /$ fed alone or combined with potassium humate, while the increases of $\mathrm{N}, \mathrm{P}$ and $\mathrm{K}$ concentration in seeds plants as treated with bio-fertilizers combined with mineral fertilizers rate at $20-25-30 \mathrm{NPK} \mathrm{kg/fed.} \mathrm{Potassium}$ humate and bio-fertilizers in combination with NPK chemical fertilizers significantly increase $\mathrm{P}$ and $\mathrm{K}$ concentration in seeds in both seasons, while the $\mathrm{N}$ concentration significantly increased in the second season. The different rate of mineral fertilizers gave significantly increased of $\mathrm{P}$ and $\mathrm{K}$ concentrations in pea seeds with increasing rates in both seasons, while $\mathrm{N}$ concentration significantly increased in the second season. These results are in agreement with Tenshia and Singaram (2005), they indicated that the potassium humate application at a rate of $20 \mathrm{~kg} / \mathrm{ha}$ improved the availability and uptake of macronutrients in plants. Moreover, El-Ghamry et al. (2009) reported that the application of potassium humate has significant increases of $\mathrm{N}, \mathrm{P}$ and $\mathrm{K}$ content in seed and straw of faba bean plants. Ahmad et al (2013) revealed the increase in the nutrients $\mathrm{N}, \mathrm{P}$ and $\mathrm{K}$ uptake in shoot of pea seeds as affected with potassium humate application under calcareous soil conditions. The positive effect of potassium humate on the uptake of nutrient might be due to its effect on the constancy of membrane permeability and correlated by the surface activity of potassium humate containing both hydrophilic and hydrophobic sites. El-Beheidi et al (2005) found that the applied of bio-fertilizers alone or combined with mineral $\mathrm{N}$ and $\mathrm{P}$ fertilizers significantly increased for $\mathrm{N}, \mathrm{P}$ and $\mathrm{K}$ concentration in pea seeds compared with control.

Table 7. Macronutrients concentration in seeds pea plants as affected by mineral fertilizers with or without biofertilizers or potassium humate at 120 days after sowing through 2016/2017and2017/2018 experiment seasons

\begin{tabular}{|c|c|c|c|c|c|c|c|c|c|c|c|c|}
\hline \multirow{2}{*}{ Treatment } & \multicolumn{3}{|c|}{ Minerals rates (kg/fed) } & \multicolumn{3}{|c|}{$\mathbf{N}(\%)$} & \multicolumn{3}{|c|}{$\mathbf{P}(\%)$} & \multicolumn{3}{|c|}{ K (\%) } \\
\hline & $\mathbf{N}$ & $\mathbf{P}_{2} \mathbf{O}_{4}$ & $\mathrm{~K}_{2} \mathrm{O}$ & S1* & S2** & Mean & S1 & S2 & Mean & S1 & S2 & Mean \\
\hline \multirow{4}{*}{$\begin{array}{l}\text { Mineral } \\
\text { fertilizers }\end{array}$} & 0 & 0 & 0 & 2.89 & 2.94 & 2.92 & 0.12 & 0.18 & 0.15 & 0.89 & 0.94 & 0.92 \\
\hline & 10 & 15 & 20 & 3.07 & 3.12 & 3.10 & 0.15 & 0.22 & 0.19 & 0.90 & 0.98 & 0.94 \\
\hline & 20 & 25 & 30 & 3.12 & 3.19 & 3.16 & 0.18 & 0.25 & 0.22 & 1.02 & 1.08 & 1.05 \\
\hline & 40 & 30 & 40 & 3.15 & 3.25 & 3.20 & 0.22 & 0.31 & 0.27 & 1.04 & 1.12 & 1.08 \\
\hline \multirow[t]{2}{*}{ Mean } & & & & 3.06 & 3.13 & 3.09 & 0.17 & 0.24 & 0.20 & 0.96 & 1.03 & 1.00 \\
\hline & 0 & 0 & 0 & 2.97 & 3.08 & 3.03 & 0.17 & 0.28 & 0.23 & 0.97 & 1.05 & 1.01 \\
\hline \multirow{3}{*}{ Bio-fertilizers } & 10 & 15 & 20 & 3.14 & 3.32 & 3.23 & 0.23 & 0.41 & 0.32 & 1.03 & 1.13 & 1.08 \\
\hline & 20 & 25 & 30 & 3.41 & 3.59 & 3.50 & 0.36 & 0.46 & 0.41 & 1.12 & 1.18 & 1.15 \\
\hline & 40 & 30 & 40 & 3.38 & 3.44 & 3.41 & 0.33 & 0.42 & 0.38 & 1.10 & 1.14 & 1.12 \\
\hline \multirow[t]{2}{*}{ Mean } & & & & 3.23 & 3.36 & 3.29 & 0.27 & 0.39 & 0.33 & 1.06 & 1.13 & 1.09 \\
\hline & 0 & 0 & 0 & 3.04 & 3.14 & 3.09 & 0.20 & 0.24 & 0.22 & 0.98 & 1.15 & 1.07 \\
\hline Potassium & 10 & 15 & 20 & 3.48 & 3.61 & 3.55 & 0.33 & 0.38 & 0.36 & 1.12 & 1.23 & 1.18 \\
\hline \multirow[t]{2}{*}{ humate } & 20 & 25 & 30 & 3.52 & 3.75 & 3.64 & 0.41 & 0.46 & 0.44 & 1.17 & 1.25 & 1.21 \\
\hline & 40 & 30 & 40 & 3.58 & 3.80 & 3.69 & 0.42 & 0.48 & 0.45 & 1.20 & 1.32 & 1.26 \\
\hline \multicolumn{4}{|c|}{ Mean } & 3.41 & 3.58 & 3.49 & 0.34 & 0.39 & 0.37 & 1.12 & 1.24 & 1.18 \\
\hline \multicolumn{4}{|c|}{ LSD. $0.05 \%$ Rate } & ns & 0.01 & --- & 0.04 & 0.01 & ---- & 0.022 & 0.078 & --- \\
\hline \multicolumn{4}{|c|}{ LSD. $0.05 \%$ treatments } & ns & ns & ---- & ns & ns & --- & 0.013 & 0.043 & -- \\
\hline \multicolumn{4}{|c|}{ Rate $X$ treatments } & ns & $* * *$ & --- & $* *$ & $* * *$ & --- & $* * *$ & $*$ & --- \\
\hline
\end{tabular}

Micronutrients concentration in pea seeds.

Data presented in Table (8) show the effect of mineral fertilizers (NPK) combined with or without potassium humate and bio-fertilizers on $\mathrm{Fe}, \mathrm{Mn}$ and $\mathrm{Zn}$ concentrations $(\mathrm{mg} / \mathrm{kg})$ in pea seeds in the two seasons .Results showed that $\mathrm{Fe}, \mathrm{Mn}$ and $\mathrm{Zn}$ concentrations were increased with increasing rate of chemical fertilizers as compared without bio-fertilizers and potassium humate. Mineral fertilizers significantly increased Fe, Mn and $\mathrm{Zn}$ concentrations in pea seeds in both seasons, while the significant increases of $\mathrm{Mn}$ and $\mathrm{Zn}$ concentrations in seeds treated with all treatments were obtained in the second season ,.On the other hand, Fe concentration in pea seeds was unsignificant in both seasons. The interaction between all treatments and different mineral rates caused significant increases in $\mathrm{Fe}, \mathrm{Mn}$ and $\mathrm{Zn}$ concentrations in pea. The highest mean values of $\mathrm{Fe}, \mathrm{Mn}$ and $\mathrm{Zn}$ concentrations were obtained in pea seeds .A plants treated with potassium humate in both seasons. Also, the increase of Fe, Mn and $\mathrm{Zn}$ concentrations in pea seeds of plants treated with bio- 
fertilizer combined with mineral fertilizers 20- $25-30$ NPK is higher than bio-fertilizers alone. The relative increases of mean values were $7.47 \%$ for Fe; $15.65 \%$ for $\mathrm{Mn}$ and $2.00 \%$ for $\mathrm{Zn}$ concentrations in seeds of pea plants treated with mineral fertilizers at different rates compared without mineral fertilizers in both seasons. On the other hand, the relative increases of mean values $11.60 \%$ for $\mathrm{Fe}$ ; $60.49 \%$ for $\mathrm{Mn}$ and $39.28 \%$ for $\mathrm{Zn}$ concentrations in seeds of pea plants treated with bio-fertilizers combined with mineral fertilizers rates were higher than without mineral fertilizers. As well as, the relative increases of mean values $17.89 \%$ for $\mathrm{Fe} ; 81.60$ for $\mathrm{Mn}$ and $28.66 \%$ for $\mathrm{Zn}$ concentrations in pea seeds of plants treated with potassium humate combined with different rates of mineral fertilizers. These results may be attributed to potassium humate enhanced cell permeability, which in turn made more rapid entry of minerals into root cells and so resulted in higher concentrations of plant nutrients. In addition, the application of potassium humate increased nutritional capacity, increased reserve of slow release nutrients, enhanced solubility of Fe, Mn and $\mathrm{Zn}$. These results are in agreement with Asik et al (2009), they reported that application of potassium humate at $2 \mathrm{~g} / \mathrm{kg}$ increased $\mathrm{Fe}$, $\mathrm{Mn}$ and $\mathrm{Zn}$ uptake in plants under saline soil. In addation, Hanafy et al (2010) showed that the application of potassium humate at rate of $20 \mathrm{~g} / \mathrm{L}$ increased $\mathrm{Fe}, \mathrm{Zn}$ and Mn uptake in snap bean plants. bio-fertilization $+40 \mathrm{~kg} \mathrm{~N}$ $\mathrm{ha}^{-1}$ treatment was the most effective for increasing the uptake of $\mathrm{Fe}, \mathrm{Mn}, \mathrm{Zn}$ and $\mathrm{Cu}$ as compared to the other treatments. These increases may be attributed to the role of microorganisms in improving micronutrients availability, which was likely attributed to several reasons: 1) releasing of these nutrients through microbial decomposition of organic materials in soil; 2) lowering the $\mathrm{pH}$ of soil making the nutrients more available; and 3) lowering the redox statues of iron and manganese leading to reduction of higher $\mathrm{Fe}^{3+} \& \mathrm{Mn}^{4+}$ to $\mathrm{Fe}^{2+}$ and $\mathrm{Mn}^{2+}$ and/or transformation of insoluble chelated forms of micronutrients into more soluble ions(Helmy et al ,2013).

Table 8. Micronutrients concentration in pea seeds as affected by mineral fertilizers with or without bio-fertilizers or potassium humate at 120 days after sowing through 2016/2017and2017/2018 experiment seasons

\begin{tabular}{|c|c|c|c|c|c|c|c|c|c|c|c|c|}
\hline \multirow{2}{*}{ Treatment } & \multicolumn{3}{|c|}{ Minerals rates (kg/fed) } & \multicolumn{3}{|c|}{$\mathrm{Fe}(\mathrm{mg} / \mathrm{kg})$} & \multicolumn{3}{|c|}{ Mn (mg/kg) } & \multicolumn{3}{|c|}{ Zn (mg/kg) } \\
\hline & $\mathbf{N}$ & $\mathbf{P}_{2} \mathbf{O}_{4}$ & $\mathrm{~K}_{2} \mathrm{O}$ & S1* & S2** & Mean & S1 & S2 & Mean & S1 & S2 & Mean \\
\hline & 0 & 0 & 0 & 36.04 & 36.52 & 36.28 & 21.58 & 21.85 & 21.72 & 7.95 & 8.02 & 7.99 \\
\hline Mineral & 10 & 15 & 20 & 37.84 & 37.86 & 37.85 & 23.14 & 23.86 & 23.50 & 8.05 & 8.12 & 8.09 \\
\hline \multirow[t]{2}{*}{ fertilizers } & 20 & 25 & 30 & 38.95 & 39.14 & 39.05 & 24.65 & 25.62 & 25.14 & 8.09 & 8.18 & 8.14 \\
\hline & 40 & 30 & 40 & 38.94 & 41.20 & 40.07 & 26.47 & 26.96 & 26.72 & 8.16 & 8.25 & 8.21 \\
\hline \multirow[t]{2}{*}{ Mean } & & & & 37.94 & 38.68 & 38.31 & 23.96 & 24.57 & 24.27 & 8.06 & 8.14 & 8.10 \\
\hline & 0 & 0 & 0 & 36.85 & 37.13 & 36.99 & 22.14 & 22.95 & 22.55 & 8.05 & 8.09 & 8.07 \\
\hline \multirow{3}{*}{ Bio-fertilizers } & 10 & 15 & 20 & 38.95 & 38.90 & 38.93 & 35.63 & 36.93 & 36.28 & 9.46 & 10.94 & 10.20 \\
\hline & 20 & 25 & 30 & 42.15 & 43.35 & 42.75 & 36.37 & 37.00 & 36.69 & 12.85 & 13.47 & 13.16 \\
\hline & 40 & 30 & 40 & 40.05 & 39.52 & 39.79 & 35.31 & 35.88 & 35.60 & 10.14 & 10.55 & 10.35 \\
\hline \multirow[t]{2}{*}{ Mean } & & & & 39.50 & 39.73 & 39.61 & 32.36 & 33.19 & 32.78 & 10.13 & 10.76 & 10.44 \\
\hline & 0 & 0 & 0 & 37.85 & 37.92 & 37.89 & 22.25 & 22.84 & 22.55 & 8.17 & 8.20 & 8.19 \\
\hline & 10 & 15 & 20 & 42.32 & 42.77 & 42.55 & 35.66 & 37.34 & 36.50 & 11.88 & 12.96 & 12.42 \\
\hline \multirow[t]{2}{*}{ humate } & 20 & 25 & 30 & 44.35 & 45.10 & 44.73 & 40.41 & 43.14 & 41.78 & 14.63 & 16.25 & 15.44 \\
\hline & 40 & 30 & 40 & 45.62 & 47.86 & 46.74 & 43.52 & 45.84 & 44.68 & 18.63 & 18.92 & 18.78 \\
\hline Mean & & & & 42.54 & 43.41 & 42.97 & 35.46 & 37.29 & 36.38 & 13.33 & 14.08 & 13.71 \\
\hline \multicolumn{4}{|c|}{ LSD. $0.05 \%$ Rate } & 2.62 & 0.99 & --- & 0.96 & 1.80 & --- & 2.59 & 1.36 & --- \\
\hline \multicolumn{4}{|c|}{ LSD. $0.05 \%$ treatments } & ns & ns & ---- & $\mathrm{ns}$ & 1.32 & ---- & $\mathrm{ns}$ & 0.76 & ---- \\
\hline \multicolumn{4}{|c|}{ Rate $\mathrm{X}$ treatments } & $*$ & $* * *$ & --- & $* * *$ & $* * *$ & --- & $* * *$ & $* * *$ & --- \\
\hline
\end{tabular}

*S1 first season $*$ S2 second season

Effect potassium humate and biofertilizers alone or combined with mineral fertilizers on pea seeds quality.

Data presented in Table (9) showed the effect of potassium humate and bio-fertilizers on protein (\%), carbohydrate (\%), chlorophyll (mg/g f.w) and total sugar (\%) were non-significant in both seasons, while the proline (\%) was significant in first season. The different rates of mineral fertilizers application led to significant increases in carbohydrate and proline contents in pea plants in both seasons. Protein and chlorophyll contents in pea plants were significantly increased with increasing rate of minerals in the second season, while the total sugar content was significantly increased with increasing rate in first season. The interaction between all treatments and mineral fertilizers rates led to significant increases in carbohydrate and proline contents in pea plants in both seasons, while the total sugar content was unsignificant in both seasons. The heights mean values of protein, carbohydrate, total chlorophyll and total sugar content were obtained in pea plants treated with potassium humate combined with the highest rate of mineral fertilizers. The low proline The low proline contents were found in pea plants treated with potassium humate combined with mineral fertilizers followed by bio-fertilizers this result may be to the decreases in soil salinity. Proline content in shoot plants had significantly increased as affected by bio-fertilizers and potassium humate under saline soil. These results are in agreement by Zaghloul et al (2015), who indicated that the highest values of total protein in pea seeds were observed in plants inoculated with biofertilizers. Meganid et al (2015) reported that the potassium humate application has positive effects on chlorophyll content under salinity stress. Bakry et al (2015) found that the potassium humate at rate of $20 \mathrm{mg} / \mathrm{l}$ caused significant increases in total chlorophyll compared with control. This positive effect of potassium humate on photosynthetic pigments could be attributed to an increase in $\mathrm{CO}_{2}$ assimilation and photosynthetic rate. Salama (2011) reported that the application of biofertilizers improved carbohydrates content in spinach plants and significantly increased under saline soil. 
Table 9. Pea seeds quality pea plants as affected by mineral fertilizers with or without bio-fertilizers or potassium humate at 120 days after sowing through 2016/2017and2017/2018 experiment seasons.

\begin{tabular}{|c|c|c|c|c|c|c|c|c|c|c|c|c|c|c|c|c|c|c|}
\hline \multirow[t]{2}{*}{ Treatment } & \multicolumn{3}{|c|}{$\begin{array}{c}\text { Minerals rates } \\
\text { (kg/fed) }\end{array}$} & \multicolumn{3}{|c|}{$\begin{array}{l}\text { Protein } \\
(\%)\end{array}$} & \multicolumn{3}{|c|}{$\begin{array}{c}\text { Carbohydrate } \\
(\%)\end{array}$} & \multicolumn{3}{|c|}{$\begin{array}{c}\text { Total chlorophyll } \\
\text { (mg/g f.w.) }\end{array}$} & \multicolumn{3}{|c|}{$\begin{array}{c}\begin{array}{c}\text { Total sugar } \\
(\%)\end{array} \\
\end{array}$} & \multicolumn{3}{|c|}{$\begin{array}{l}\text { Proline } \\
\text { (\%) }\end{array}$} \\
\hline & $\mathbf{N}$ & $\mathrm{P}_{2} \mathrm{O}_{4}$ & $\mathrm{~K}_{2} \mathrm{O}$ & S1 & S2 & Mean & S1 & S2 & Mean & S1 & S2 & Mean & S1 & S2 & Mean & S1 & S2 & Mean \\
\hline \multirow{4}{*}{ Control } & 0 & 0 & 0 & 18.06 & 18.38 & 18.22 & 43.52 & 44.85 & 44.19 & 34.62 & 34.95 & 34.79 & 12.95 & 13.85 & 13.40 & 62.34 & 57.62 & 59.98 \\
\hline & 10 & 15 & 20 & 19.19 & 19.50 & 19.35 & 46.95 & 48.41 & 47.68 & 35.10 & 35.66 & 35.38 & 14.10 & 14.55 & 14.33 & 57.23 & 51.69 & 54.46 \\
\hline & 20 & 25 & 30 & 19.50 & 19.94 & 19.72 & 48.34 & 49.66 & 49.00 & 37.38 & 38.00 & 37.69 & 14.97 & 15.26 & 15.12 & 50.34 & 46.82 & 48.58 \\
\hline & 40 & 30 & 40 & 19.69 & 20.31 & 20.00 & 50.37 & 51.94 & 51.16 & 37.95 & 38.89 & 38.42 & 15.14 & 15.86 & 15.50 & 49.37 & 40.98 & 45.18 \\
\hline Mean & & & & 19.11 & 19.53 & 19.32 & 47.30 & 48.72 & 48.01 & 36.26 & 36.88 & 36.57 & 14.29 & 14.88 & 14.59 & 54.82 & 49.28 & 52.05 \\
\hline \multirow{4}{*}{$\begin{array}{l}\text { Bio- } \\
\text { fertilizers }\end{array}$} & 0 & 0 & 0 & 18.56 & 19.25 & 18.91 & 44.34 & 45.82 & 45.08 & 35.06 & 36.04 & 35.55 & 13.08 & 13.95 & 13.52 & 60.48 & 55.74 & 58.11 \\
\hline & 10 & 15 & 20 & 19.63 & 20.75 & 20.19 & 47.40 & 49.75 & 48.58 & 36.87 & 37.14 & 37.01 & 14.75 & 14.99 & 14.87 & 54.32 & 46.79 & 50.56 \\
\hline & 20 & 25 & 30 & 21.31 & 22.44 & 21.88 & 49.85 & 51.10 & 50.48 & 37.16 & 37.85 & 37.51 & 15.23 & 15.88 & 15.56 & 46.32 & 39.25 & 42.79 \\
\hline & 40 & 30 & 40 & 21.13 & 21.50 & 21.32 & 49.67 & 50.98 & 50.33 & 37.94 & 38.25 & 38.10 & 16.30 & 16.91 & 16.61 & 37.65 & 33.41 & 35.53 \\
\hline Mean & & & & 20.16 & 20.98 & 20.57 & 47.82 & 49.41 & 48.61 & 36.76 & 37.32 & 37.04 & 14.84 & 15.43 & 15.14 & 49.69 & 43.80 & 46.75 \\
\hline \multirow{4}{*}{ Humic acid } & 0 & 0 & 0 & 19.00 & 19.63 & 19.32 & 45.00 & 46.22 & 45.61 & 35.44 & 36.42 & 35.93 & 13.55 & 14.00 & 13.78 & 58.34 & 53.91 & 56.13 \\
\hline & 10 & 15 & 20 & 21.75 & 22.56 & 22.16 & 49.74 & 50.66 & 50.20 & 38.32 & 38.95 & 38.64 & 15.04 & 15.19 & 15.12 & 43.25 & 42.83 & 43.04 \\
\hline & 20 & 25 & 30 & 22.00 & 23.44 & 22.73 & 53.11 & 54.39 & 53.75 & 39.42 & 40.37 & 39.90 & 15.86 & 15.99 & 15.93 & 38.10 & 35.89 & 37.00 \\
\hline & 40 & 30 & 40 & 22.38 & 23.75 & 23.07 & 55.87 & 57.82 & 56.85 & 41.22 & 40.89 & 41.06 & 16.13 & 16.75 & 16.44 & 31.52 & 27.43 & 29.48 \\
\hline Mean & & & & 21.28 & 22.34 & 21.81 & 50.93 & 52.27 & 51.60 & 38.60 & 39.16 & 38.88 & 15.15 & 15.48 & 15.31 & 42.80 & 40.02 & 41.41 \\
\hline \multicolumn{4}{|c|}{ LSD. $0.05 \%$ Rate } & ns & 1.44 & --- & 4.42 & 1.39 & ---- & ns & 1.90 & ---- & 0.86 & ns & --- & 2.57 & 6.67 & ---- \\
\hline \multicolumn{4}{|c|}{ LSD. $0.05 \%$ treatments } & ns & ns & ---- & ns & ns & --- & ns & Ns & --- & ns & ns & --- & 0.86 & ns & ---- \\
\hline \multicolumn{4}{|c|}{ Rate $\mathrm{X}$ treatments } & ns & $*$ & $\begin{array}{ll}--- \\
--\end{array}$ & $*$ & $* * *$ & $\begin{array}{ll}--- \\
\end{array}$ & $*$ & Ns & ---- & ns & ns & --- & $* * *$ & $* *$ & ---- \\
\hline
\end{tabular}

\section{CONCLUSION}

According to these results, since soil salinity causes high yield losses on pea, cultivation of this crop under saline soil conditions. Potassium humate or Biofertilizers application can reduce soil salinity by reducing application of fertilizers, improving soil fertility by fixing atmospheric $\mathrm{N}_{2}$, solubilizing insoluble soil phosphate and potassium availability. Potassium humate and bio-fertilizers have the potential to increase of vegetable crops, improve growth, yield and its components and reduce soil salinization.

\section{REFERENCES}

Abd El-Hadi , A.H. (2004). Country Report on Egyptian Agriculture. IPI regional workshop on Potassium and Fertigation development in West Asia and North Africa ; Rabat, Morocco, 24-28 November, 2004. 1:15.

Afifi, M.H .M., Mohamed M.F. \& Shaaban H.A. (2010). Yield and nutrient uptake of some faba bean varieties grown in newly cultivated soil as affected by foliar application of potassium humate. J. of Plant Production, 1(1), $77-85$

Ahmad, K.; Ali, R. G.; Muhammad, Z. K. ; Fayyaz, H.; Muhammad, K.; Khan, S. and Abdullah. K. (2013). Effect of potassium humate on the growth, yield, nutrient composition, photosynthetic pigment and total sugar contents of pea (pisum sativum L). J. Chem. Soc. Pak. 35 (1): 206- 211.

Ali, M. A.; El-Gendy, S. S. and Ahmed, O. A. (2013). Minimizing adverse effects of salinity in vineyards. J. Hort. Sci. \& Ornamen. Plants, 5(1): $12-21$.

Asik, B. B.; Turan, M. A.; Celik, H. and Katkat, A. V. (2009). Effects of humic substances on plant growth and mineral nutrients uptake of wheat (Triticum durum cv. Salihli) under conditions of salinity. Asian J. Crop Sci., 1(2):87-95.

Bakry, A. B.; Sadak, M. Sh. And El-Karamany, M. F. (2015). Effect of potassium humate and sulphur on growth, some biochemical constituents, yield and yield attributes of flax grown under newly reclaimed sandy soils. ARPN. J. of Agric. and Biological Sci. 10 (7): 247- 259.
Bhat, T.A.; Gupta, M.; Ganai, M.A.; Ahanger, R.A. and Bhat, H.A. (2013). Yield, soil health and nutrient utilization of field pea (Pisum sativum L.) as affected by phosphorus and Biofertilizers under subtropical conditions of Jammu, International journal of modern plant and animal science, 1(1):18.

Brunner, P. H. and H. R. Wasmer (1978) Methods of analysis of sewage sludge solid wastes and compost W.H.O. International Reference Center for Wastes Disposal (H-8600) Dulendrof Switzerland.

Chapman, H.D. and P.F. Pratt (1961). Methods of Analysis for Soils, Plants and Water. Agric. Publ. Univ., of California, Reverside.

Cottenie, A.; M. Verloo; G. Velghe and R. Cameriynck (1982). "Chemical Analysis of plant and soil. " Laboratory of analytical and Agrochemistry, State Univ., Ghent, Belgium.

El-Bassiony, A. M.; Fawzy, Z. F.; Abd El-Baky, M. M. H. and Mahmoud, A. R. (2010). Response of snap bean plants to mineral fertilizers and potassium humate application. Res. J. Agric. Biol. Sci., 6(2):169-175.

El-Beheidi, M.A.; El-Mansi, A.A.; Ramadan, M. M. (2005). Effect of mineral and biofertilizers on growth, yield and quality of pea plants under sandy soil conditions. Zagazig J. Agric. Res. 32 (5): 14531473.

El-Ghamry, A. M.; Abd El-Hai, K. M. and Ghoneem, K. M. (2009). Amino and potassium humate promote growth, yield and disease resistance of faba bean cultivated in clayey soil. Austr. J. of Basic and Appl. Sci., 3(2):731-739.

El-Galad, M.A.; D.A. Sayed and R.M. El-Shal (2013). Effect of potassium humate and compost applied alone or in combination with sulphur on soil fertility and faba bean productivity under saline soil conditions. J. Soil Sci. and Agric. Eng., Mansoura Univ., 4(10):1139 - 1157.

Ghodia, R. H. A. (2012). Productivity improvement of cowpea under desert soil conditions. Plant Production, Mansoura Univ., 3(9): 2451- 2463.

Gomez, K. A. and A. A. Gomez (1984). Statistical Procedures For Agricultural Research. Second ed. Jon Willey and Sons Inc. NewYork, U.S.A. 
Gulser, F., Sonmez, F. and Boysan, S., (2010) . Effects of calcium nitrate and potassium humate on pepper seedling growth under saline condition. J. Environ. Biol. 31, 873-876.

Hanafy, A. A. H.; Nesiem, M. R. ; Hewedy, A. M. and Sallam, H. El. S. (2010). Effect of some simulative compounds on growth, yield and chemical composition of snap bean plants grown under calcareous soil conditions. J. of American Sci. 6 (10): 552- 569.

Harleen, K.; Gosal, S.K. and Walia, S. S. (2017). Integrated application of bio-fertilizers with different fertilizers affects soil health in pea crop. Chem, Sci. Rev. Lett. 6 (23): 1646- 1651.

Hassan, A. E. (2016). Effect of potassium humate on growth and productivity of Egyptian lime trees (Citrus aurantifolia Swingle ) under salt stress conditions. J . Agric. Res. Kafr El-Sheikh Univ. 42 (4): 494- 505.

Helmy, A. M. ; Shaban, Kh. A. and Abdel Kader, M. G. (2013). Rhizobium biofertilization with or without mineral fertilization for a new cowpea cultivar (Kafer El-Sheikh 1) grown under saline conditions. Zagazig J. of Agric. Res. 40 (5): 891- 906.

Hussein, Kh. And Hassan, A. F. (2011). Effect of different levels of potassium humates on the nutrient content, plant growth, and soil properties under conditions of salinity. Soil and Water Res. 6 (1): 21- 29.

Hymowitz, T.F. ; P. Collins and W.M. Walker (1972). Relationship between the content of oil, protein and sugar in soybean seed. Agron. J., 64: 613-616

Klute, A. (1986). Methods of Soil Analysis. Part 1, American Society of Agronomy, Inc. Soil. Soc. of Amer., Inc. Madison Wisconsin , U.S.A. Second Edition.

Meganid , A.. S.; Hassan, S. A. and El-Metwally, M. S. (2015). Effect of potassium humate application on growth and chlorophyll contents of common bean plants (Phaseolus vulgaris L. ) under salinity stress conditions. Intr. J. of Innovative Res. In Sci. Eng. And Tech. 4 (5): 2651- 2660.

Mohamed, W. H. (2012). Effect of potassium humate and calcium forms on dry weight and nutrient uptake of maize plant under saline condition. Austr. J. Basic and Appli. Sci. 6 (8): 597 -604.

Page, A.L. ; R. H. Miller and D. R. Keeny (1982). Methods of Soil Analysis. Part 2- Chemical and Microbiological Properties second Edition Ajner. Soc. of Agron. Madison, Wisconsin, USA. 5371.

Ouni, Y.; Ghnaya, Y.; Montemurro, F.; Abdelly, Ch. and Lakhdar, A. (2014). The role of humic substance in mitigating the harmful effect of soil salinity and improve plant productivity. Inter. J. of plant production 8 (3): 354- 374.
Rather SA, Hussain MH and Sharma, ML (2010). Effect of biofertilizers on growth yield and economics of field pea (Pisum sativum L.), International Journal of Agricultural Science , 6 (1): 65-66.

Salama, O.A.A. (2010). Utilization of biofertilizers and organic sources in arable soils under saline conditions using tracer. Ph.D. Theis Fac. of Agric. Al-Azhar Unvi Cairo Egypt.

Sarg. M.H.S. and Hassan, M.A.H. (2003) Effect of Rhizobium inoculation, nitrogen fertilization and plant density on growth, yield and minerals content of pea under sandy soil conditions. J. Agric. Sci ., Mansoura. Univ., 28(11): 6857-6873.

Sarwar, M.; Ehsan, M. K .; Hyder, S. I. and Zameer, M. K. (2012). Effect of biostimulant (Potassium humate) on yield, phosphorus, potassium and boron use efficiency in peas. Persian Gulf Crop Protection, 1(4):11-16.

Shaban, Kh . A. and Attia , A. M (2009). Evaluation of bio- and chemical fertilizers applied to corn grown on a saline sandy soil. Minufiya J. Agric. Res. Vol. 34 No (3) : 1311 - 1326.

Shadisadat Mohajeranil, Mojtaba Alavi fazel, Hamid Madani, Shahram Lak and Adel Modhej(2016). Effect of the foliar application of humic acid on red bean cultivars (Phaseolus vulgaris L.) Journal of Experimental Biology and Agricultural Sciences, August - 2016; Volume - 4(5)

Sushila, A.; Yadav, BL .; Bhuli, D. G and Jitendra, S B. (2017). Effect of soil salinity, phosphorus and biofertilizers on physical properties of soil, yield attributes and yield of cowpea [Vigna unguiculata (L.) Wilczek. J. of Pharmacognsy and Phytochemistry. 6 (4): 1691- 1695.

Tenshia, J; S. V. and Singaram, P. (2005). Influence of potassium humate application on availability and uptake in tomato. The Madrass Agric. J. 92:670 676.

Wu, S.C.; Luo, Y. M.; Cheung, K.C. and Wong, M.H. (2006). Influence of bacteria on $\mathrm{Pb}$ and $\mathrm{Zn}$ speciation, mobility and bio-availability in soil. Environmental Pollution, 144 (3): 765 - 773.

Zaghloul, R. A.; Abou Ali, H.E.; El-Meily, R. M. and Mohamed, T. E. (2015). Improvement of growth and yield of pea plants using integrated fertilization management. Universal J. of Agric. Res. 3 (4): 135 -143 .

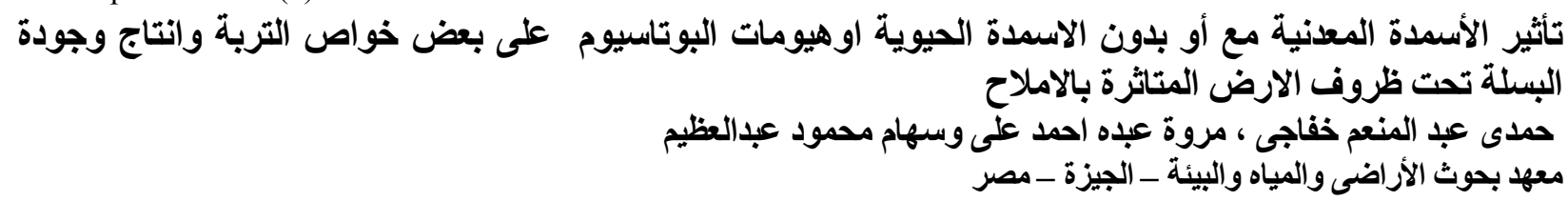

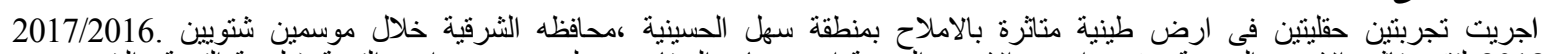

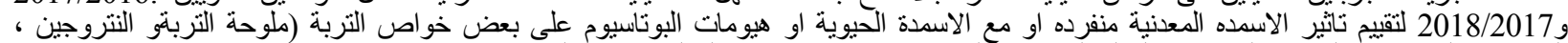

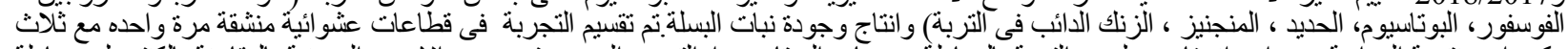

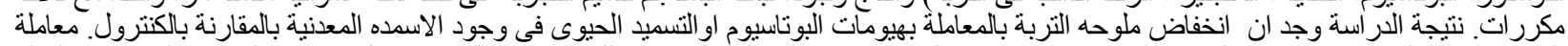

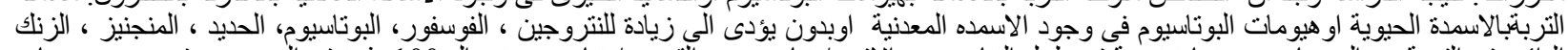

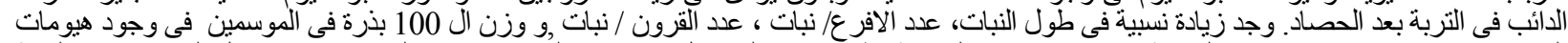

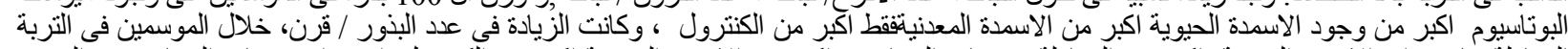

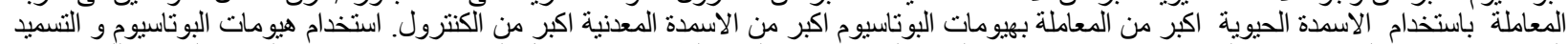

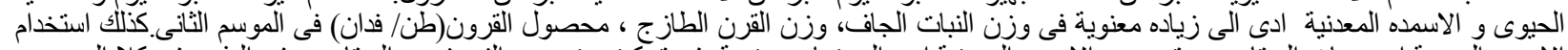

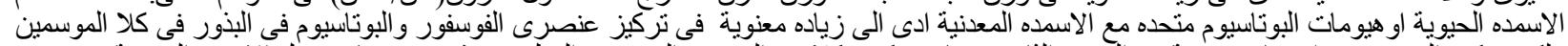

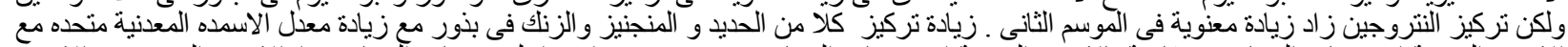

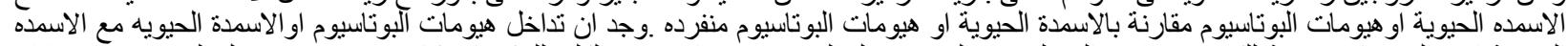

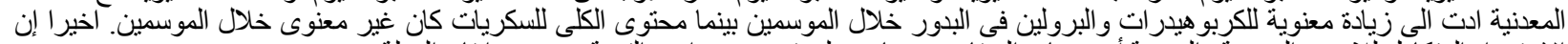

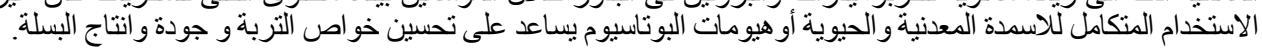

